\title{
THE GRADUATE TRACKING AND ATTAINMENT MODEL AT THE UNIVERSITY OF PÉCS
}

\author{
NORBERT SIPOS \\ sipos.norbert@pte.hu \\ University of Pécs, Hungary \& \\ Eötvös József College, Hungary \\ Gabriella Kuráth \\ kurath.gabriella@pte.hu \\ University of Pécs, Hungary
}

\begin{abstract}
The aim of this study is to provide an overview of the Hungarian higher education system facing changes since 1990. The three major challenges are: the decreasing number of students enrolling since the 'golden age' ended; the Bologna-Process and its influence since its introduction in 2006 and the uncertainty about the future role of the state in educational finance. The institutions have to take these changes and the effects on their situation into account and they need to find a way to benefit from them. Thanks to Graduate Follow-Up System (GFS) research, they can measure the new graduates performance on the labour-market, their job-related satisfaction levels and possibilities, and furthermore they can have direct information about employers' expectations, first of all on the level of working skills. This information can be used for the creation of a different approach of how to think about the students and which services could be offered to them. In the following analysis we use data from research conducted in the last three years at the University of Pécs.

The focused energy and resource investment is more effective if it is based on specific training and education packages offered within the Alumni framework. It can increase the results of an even more successful Alma Mater service; furthermore it can improve the self-identification of the institution, therefore it is important to have a long-term strategy.

Key words: Higher education, Graduate Follow-Up System, Career tracking, Labour market skills, University of Pécs, Alumni Program
\end{abstract}

\section{INTRODUCTION}

In Hungary, there have been several changes in the higher education system since the regime change in 1990. First, it became commonplace to continue studies to a higher educational level, so institutions and faculties spread across the country (the number of institutions increased from 77 in 1990 to 91 in 1994, which decreased to 62 by the millennium and nowadays is 66; the number of faculties increased from 117 in 1990 to 184 in 2011) and the offer of different types of courses greatly increased (Oktatási Hivatal, 2012) ${ }^{1}$. According to the data of the Hungarian Central Statistical Office, in 1990 only 102 thousand students participated in higher education, while in 2011 there were more than 360 thousand students. This

Hungarian Education Office 
means that the number of students almost quadrupled in the higher education system in the last two decades. At first glance it seems to be a good tendency but after a closer look the problems and future problems come to light. The peak of this expansion was reached in 2005 with 424 thousand participants, since then it has been steadily decreasing $\left(\mathrm{KSH}^{2} 2012\right)$, and will probably continue due to the general phenomena of the Hungary's aging population accompanied by the declining birth rate.

The second major challenge is the adoption of the Bologna Process in the higher education system. The objectives of the Bologna declaration were agreed in 1999 in Bologna (in Hungary it is widely known as the Bologna Process) and every participating country agreed to create the basis of higher education reform which was successful from this point of view. The main aim of the Bologna Process was the development of a European Higher Education Area (EHEA), an easy to understand and comparable education system. The training cycle became two-tiered in most of the study programs, with a flexible credit system to facilitate European cooperation in assuring standards of higher education and to support the European dimension of higher education (Szolár, 2009). In Hungary, the new education system was introduced in 2006. The most important aim of the Bologna Process is to promote student mobility, European diversity, multicultural character and to encourage students to get to know each other. The Hungarian competitive situation must be measured in itself, however, it is also connected to the wider regions, Europe and the world, and the Bologna Process thus aims to influence higher education. In this competition, the main task of the Hungarian Higher Education strategy is to reach and maintain a good position not only concerning the whole of Hungary but several, structured institutions as well, which are simultaneously affecting each other on the global level.

The third major challenge is the continued uncertainty of the government (the article was written in December, 2012) about the future situation of the number of state-financed places. Government funding had always played a dominant role in higher education in Hungary (primary and secondary education is accessible and free for every citizen, which is one of the fundamental rights provided by the Constitution of Hungary) (Magyar Közlöny, 2011b), because in a 10 year average $80 \%$ of the costs of the students in full time training and $55-60 \%$ in total was financed by the state. 2012/2013 was the first academic year with a dramatic change, because state-financed places were reduced to 31,750 (Magyar Közlöny, 2012) which is 50\% of the previous year (the number of the higher education applicants and admitted students decreased too, but not at this rate, because in 2011 115,841 students were admitted and in 2012 only 84,694) (Felvi. $\mathrm{hu}$ ). To complete the picture we have to add that the government introduced a third form of financing: the partially state-financed place, the number of which is approximately half of the state-financed places. (For the 3 major changes see Figure 1.)

KSH is the acronym of the Hungarian Central Statistical Office. 


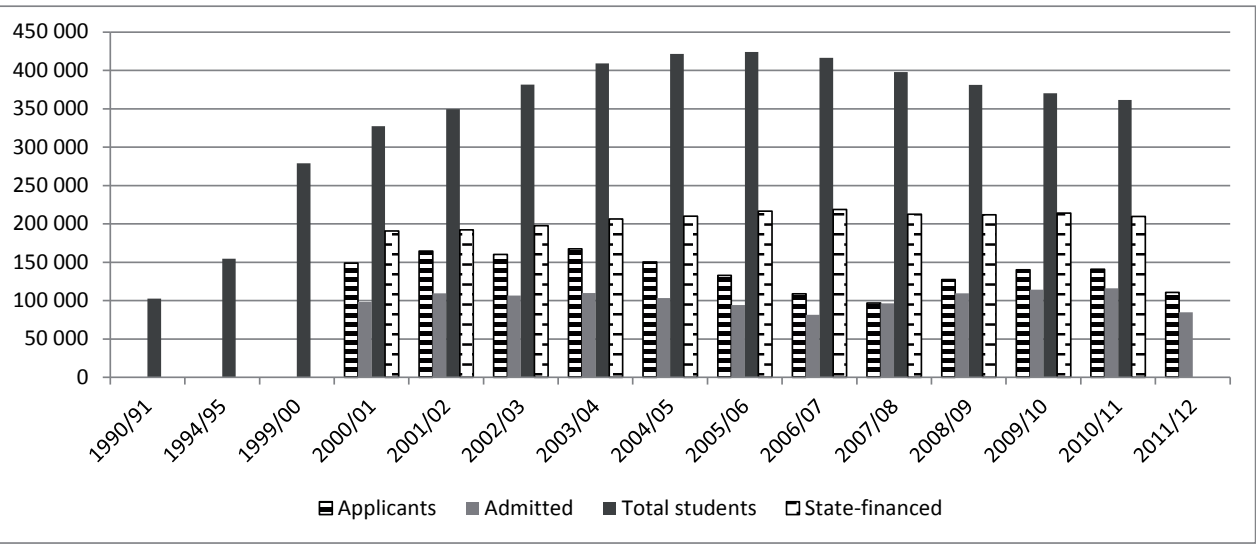

Figure 1. The applicants, admitted, state-financed and total number of students of the Hungarian higher education system, 1990-2012.

Source: Author's diagram based on: KSH 2012; Felvi.hu 2012.

These changes challenge every higher education institution to develop their own strategy concerning long-term operations, because previously they responded to the increased demand for their services and now it seems that the 'golden age' is over. They need to review their own role in the Hungarian and macro-regional environment and their relationship with the students. It is important to get an exact overview of their output 'product', namely the graduates' performance on the labour-market. Important conclusions can be drawn based on their success and current situation, which can help determine the main priorities of the strategy concerning current students. Information about salary, characteristics of the professional position and development, family and regional structure can guide the institutions towards the identification of the necessary and competitive factors. Therefore the institutions can make indispensable changes to achieve a higher level and more intensive aspiration among potential students to be a part of their system, because the success of a university is to provide the economy with a skilled labour force and to reduce the unemployment rate. This task is very difficult, because there is at least a 3-4 year delay between the results of a new higher education period and the dynamically changing needs of the market. To strengthen the efficiency of the reaction the institutions have to use several different methods to be up to date concerning the labour-market competition and therefore the higher education competition as well. It can be observed as a multi-level competition, and the labour-market placement as well as the placement ratio of those graduates who practice a profession on the field related to their studies are without doubt the best objective measure of success.

In a wider context even the political and economic strategic planning processes need information to create a good educational system and to allocate the necessary financial resources. The Hungarian Higher Education Act was completely restructured and changed in the last quarter of 2011 and the CCIV. Higher Educa- 
tion Act about the National Higher Education of 2011 very precisely determines the aims of the government. Namely, the Higher Education Information System (HEI) dedicated a whole chapter (Chapter 10) to describe the rights and obligations of an institution in carrying out its main tasks. They have to develop and operate different types of information collection methods, whose data can be aggregated and integrated into a national database (of course at the same time ensuring the maximum level of anonymity). This database serves as a basic input for the strategic education-related decisions and it can definitely influence the distribution of state-financed places among the institutions even if the opposite is communicated. This part of the Higher Education Act contains the obligatory task of universities and colleges to repeatedly conduct and evaluate a survey every year among the graduates and the current students. The Act prescribes this task from 2007 onwards; therefore there was an intensive period to create a supportive system and an organization, the Educatio Non-profit Ltd. which provides the higher education providers with survey software, an elaborated common national questionnaire and useful technological solutions. This survey and the information collection process is called and widely known in Hungary as Graduate Follow-Up System (GFS). In the launching phase of GFS design the primary criterion was not to create any type of ranking methodology so that the institutions could have an open-minded attitude towards this initiative. It is not used for a direct ranking, but as the HEI concept states in the Higher Education Act, 46. §, "the Government shall set the quota for newly admitted students annually ... with labour-market forecasts, the data of the career monitoring system ...". (Magyar Közlöny, 2011a, p. 41,200) Therefore, indirectly, a ranking is realized based on costs. Despite the potential threats, we think that a decision based on very complex and structured surveys can bring a more realistic and acceptable result.

The aim of the GFS is to help institutions and in our case namely the University of Pécs (UP) to allocate the necessary resources and to act accordingly to face these changes. The University of Pécs with its 26,669 students in 2011 (pte.hu) has a $7.74 \%$ share of the Hungarian higher education system; it is among the five biggest institutions of Hungary. UP has suffered from the above mentioned changes by losing one-third of its students from 2006, thus it is extremely important to analyze the situation of the graduates and to attain them by providing useful services and trainings within the framework of the Alumni Program.

\section{METHODOLOGY}

The study consists of the results and analysis of the Graduate Follow-Up System (GFS) survey carried out among students participating in higher education at the University of Pécs and the conclusions drawn from the UP Alumni Program. The Graduate Follow-Up System consists of two main parts: the graduates' survey and the current students survey. The aim of the latter is to fulfill a service monitoring task: by reaching the students participating in the current education process with these questionnaires, the institution can assure the quality of the services, due to the continuous perfection of the relevance-satisfaction indicators, which 
are essential for the maintenance of competitiveness of Hungarian HE institutions. The survey for graduates monitors the labour-market status of the graduates, collects information about the completed courses, the students' future plans, social conditions and income situation. This is part of the after graduation feedback of the institutional service improvement plan and therefore it is more complicated and complex compared to the students' survey, since the institutions need to question those who graduated 1,3 and 5 years earlier. According to a widely accepted view, the graduate labour-market situation does not change significantly in 1 or 3 years and should rather be examined only every 5 years, although in the start-up phase, important information might emerge. In the long term, maintaining continuous contact may well increase the willingness of former students to complete the questionnaires. Furthermore this means that an institution has to reach its former students after 5 years, which is a very difficult task, if a consistent and relevant contact list is not available. Where the Alumni system is functioning at a high level, this is easy, but where this specific kind of career tracking system was not created it might be nearly impossible to reach the graduates. We have to consider this factor, because on one hand a higher response rate can give a more precise picture about the current situation of former students, and on the other hand the majority of the institutions had to correspond to a minimal level (15\%) of response rate, as they were obligated in the Social Renewal Operational Program. (This project targeted the HE institutions to develop the GFS System.)

Therefore the Higher Education providers face various difficulties in fulfilling their obligation to carry out the GFS surveys among the students and the graduates and they have to find the right actions. By analyzing the different opportunities and available tools maybe they can turn this new situation to their favor, namely by creating an effective Alumni system which allows a different approach on how to gain new markets, and how to increase their market share.

The University of Pécs joined the GFS nationwide research program in 2010. The researches carried out in 2010, 2011 and 2012 (Kuráth et al., 2011a; 2011b; 2012) at the UP within the framework of the Graduate Follow-Up System consist of the pre-degree students of 2007 and 2009 then of 2008 and 2010 and of 2007, 2009 and 2011. 17,923 graduates who had an e-mail contact formed the database. The access rate is above $90 \%$ (comparing it to the total of the graduates, therefore we can use it as the total statistical population), so the basic population inquiry is almost complete. In the sample there are 4,388 graduates, which is a good, $24.48 \%$ access rate. This is well above the initial expectations despite the fact that a personal survey was not carried out; only the online platform was used. Based on the arguments of GFS professionals stated at several GFS-related conferences there is a well-known doubt regarding the quality of the data, what the main factor would be concerning the question about the majority of the respondents: whether there are more of those who are absolutely satisfied, or those who are unsatisfied or totally neutral. Despite this uncertainty it can be used for general and particular analysis as well and we consider it to be fully representative of the sample of the research, because all the issues of the oral survey conducted in the autumn of 2010 (within the framework of GFS every three years an oral survey is required to be carried out to 
ensure the validation of the online surveys) fully support the results of the online questionnaire. In addition to the basic examination of the representativeness of the sample it is also important to emphasize that the data was weighted according to the theoretical distribution of the full dataset taking the variables of sex, course type and faculties into account. By using this method we lose some respondents in the sense of the sample size, but it guarantees some consistency. During the crosstab analysis the significant difference was determined by taking the three criteria of the significance expectation into account: chi-square score less than 0.05 ; the minimum expected count is equal to or greater than 1 and the ratio of the cells with expected count is maximum 20\% (Sajtos, Mitev, 2007). A further difficulty of the research is that in the surveys of 2010 and 2011 several questions were changed by the Education Non-profit Ltd., so in several cases the analysis is valid only for two surveys. In these cases the sample size is indicated.

\section{THE RESUlTS OF THE GRADUATE FOLLOW-UP SYSTEM}

From 2007 to 2011, 17,923 students graduated at the 10 faculties of the University of Pécs, of whom 4,388 were surveyed in the periods of May-June of 2010, April of 2011 and April of 2012 (each year the survey covered graduates of 1 and 3 years before and in the survey of 2012 the 1, 3 and 5 years before). The different faculties have their own peculiarities regarding the number of students as we can see in Table 1. For example, the Faculty of Music and Visual Arts, as well as the Medical School, is so small that we ought to survey every graduate to get correct information about their situation. The index of their access rates is very good, almost up to the average of the other faculties, but the volume of their data is not very high. So in several cases it is impossible to draw statistically exact conclusions. In the five year average, every faculty has an access rate performance between 7.56\% (FMVA) and 32.63\% (FS).

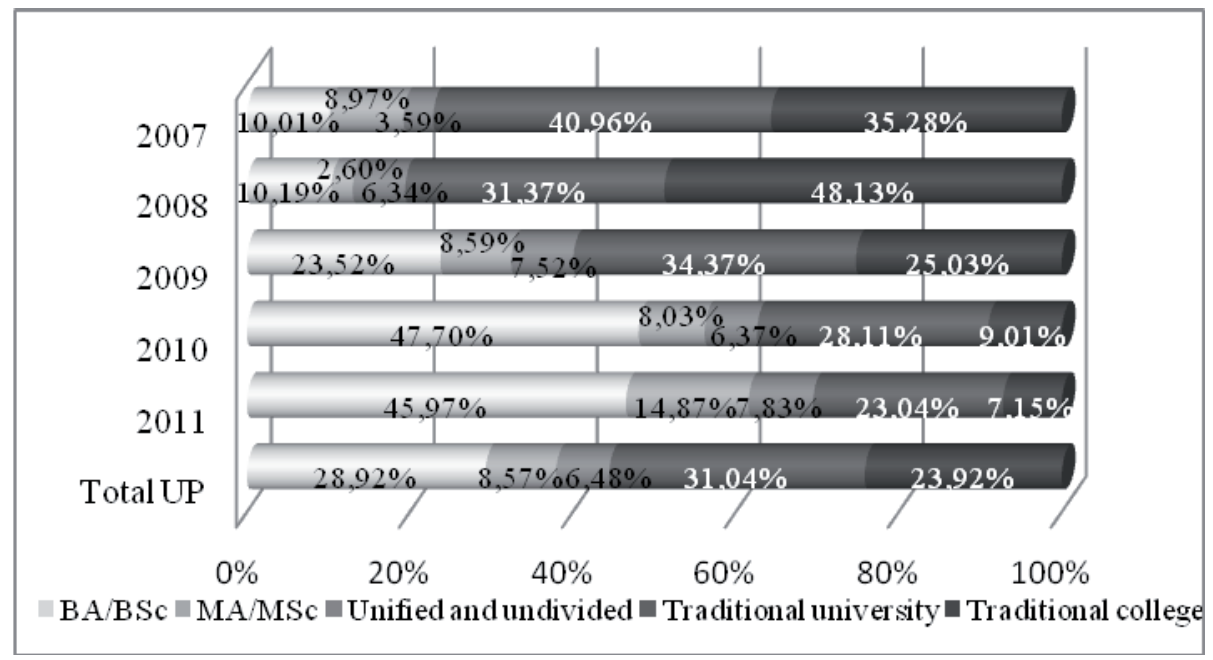

Figure 2. The graduates' study program level, 2007-2010.

Source: Authors' research. 
Table 1. The Graduate Follow-Up System data and sample size by faculties, 2007-2011.

\begin{tabular}{|c|c|c|c|c|c|c|c|c|c|}
\hline \multirow[b]{2}{*}{ Faculties } & \multicolumn{3}{|c|}{2007} & \multicolumn{3}{|c|}{2008} & \multicolumn{3}{|c|}{2009} \\
\hline & $\begin{array}{c}\text { Graduates } \\
\text { (N) }\end{array}$ & $\begin{array}{l}\text { Respon- } \\
\text { dents (n) }\end{array}$ & Rate & $\begin{array}{l}\text { Graduates } \\
\text { (N) }\end{array}$ & $\begin{array}{l}\text { Respon- } \\
\text { dents (n) }\end{array}$ & Rate & $\begin{array}{c}\text { Graduates } \\
\text { (N) }\end{array}$ & $\begin{array}{l}\text { Respon- } \\
\text { dents (n) }\end{array}$ & Rate \\
\hline FL & 556 & 98 & $17.63 \%$ & 660 & 120 & $18.18 \%$ & 574 & 91 & $15.85 \%$ \\
\hline MS & 69 & 12 & $17.39 \%$ & 144 & 32 & $22.22 \%$ & 142 & 40 & $28.17 \%$ \\
\hline FH & 693 & 112 & $16.16 \%$ & 680 & 141 & $20.74 \%$ & 1,272 & 193 & $15.17 \%$ \\
\hline FHS & 345 & 70 & $20.29 \%$ & 426 & 139 & $32.63 \%$ & 645 & 130 & $20.16 \%$ \\
\hline FAEHRD & 557 & 82 & $14.72 \%$ & 479 & 101 & $21.09 \%$ & 648 & 119 & $18.36 \%$ \\
\hline IGyFE & 258 & 49 & $18.99 \%$ & 244 & 69 & $28.28 \%$ & 288 & 62 & $21.53 \%$ \\
\hline FBE & 389 & 82 & $21.08 \%$ & 323 & 77 & $23.84 \%$ & 616 & 144 & $23.38 \%$ \\
\hline FMVA & 94 & 17 & $18.09 \%$ & 67 & 13 & $19.40 \%$ & 97 & 12 & $12.37 \%$ \\
\hline PMFEIT & 534 & 94 & $17.60 \%$ & 564 & 143 & $25.35 \%$ & 507 & 78 & $15.38 \%$ \\
\hline FS & 206 & 53 & $25.73 \%$ & 209 & 48 & $22.97 \%$ & 390 & 62 & $15.90 \%$ \\
\hline Total & 3,701 & 669 & $18.08 \%$ & 3,796 & 883 & $23.26 \%$ & 5,179 & 931 & $17.98 \%$ \\
\hline Faculties & \multicolumn{3}{|c|}{2010} & \multicolumn{3}{|c|}{2011} & \multicolumn{3}{|c|}{ Total } \\
\hline FL & 463 & 84 & $18.14 \%$ & 468 & 79 & $16.88 \%$ & 2,147 & 472 & $21.98 \%$ \\
\hline MS & 237 & 29 & $12.24 \%$ & 189 & 25 & $13.23 \%$ & 639 & 138 & $21.60 \%$ \\
\hline FH & 1,289 & 243 & $18.85 \%$ & 1,470 & 233 & $15.85 \%$ & 4,132 & 922 & $22.31 \%$ \\
\hline FHS & 602 & 115 & $19.10 \%$ & 498 & 81 & $16.27 \%$ & 1,871 & 535 & $28.59 \%$ \\
\hline FAEHRD & 469 & 87 & $18.55 \%$ & 452 & 93 & $20.58 \%$ & 1,957 & 482 & $24.63 \%$ \\
\hline IGyFE & 331 & 79 & $23.87 \%$ & 239 & 41 & $17.15 \%$ & 1,072 & 300 & $27.99 \%$ \\
\hline FBE & 718 & 155 & $21.59 \%$ & 799 & 155 & $19.40 \%$ & 2,229 & 613 & $27.50 \%$ \\
\hline FMVA & 111 & 12 & $10.81 \%$ & 119 & 9 & $7.56 \%$ & 391 & 63 & $16.11 \%$ \\
\hline PMFEIT & 442 & 120 & $27.15 \%$ & 524 & 85 & $16.22 \%$ & 2,064 & 520 & $25.19 \%$ \\
\hline FS & 467 & 100 & $21.41 \%$ & 539 & 80 & $14.84 \%$ & 1,421 & 343 & $24.14 \%$ \\
\hline Total & 5,129 & 1,024 & $19.96 \%$ & 5,297 & 881 & $16.63 \%$ & 17,923 & 4,388 & $24.48 \%$ \\
\hline
\end{tabular}

Source: Authors' research.

\section{Abbreviations:}

Faculty of Law (FL)

Medical School (MS)

Faculty of Humanities (FH)

Faculty of Health Sciences (FHS)

Faculty of Adult Education and Human Resources Development (FAEHRD)

Faculty of Illyés Gyula (IGyFE)

Faculty of Business and Economics (FBE)

Faculty of Music and Visual Arts (FMVA)

Pollack Mihály Faculty of Engineering and Information Technology (PMFEIT)

Faculty of Sciences (FS)

From this point onwards in the major part of the analysis the sample size will be 4,386 , because of the representative weighting adjustment, but as it was already indicated above there are several questions which are not identifiable and linkable in the three different surveys, so the sample size will be indicated.

Figure 2 confirms the Bologna Process' tendency in the past 5 years, we can observe the decrease of the 'traditional' and unified, undivided study program (except the non-affected professional areas of medicine and law) and a rapidly 
increasing presence of BA/BSc and MA/MSc programs. The results of 2011 will be strengthened further after 2-3 years when students of the old system graduate.

$60.26 \%$ of the former students participated in full time training, $39.74 \%$ in a correspondence course. (Evening and distant training courses were not surveyed.) The FAEHRD has the lowest rate of full time graduates $(24.90 \%)$ and the majority of the full time graduates can be seen at the MS (almost 100\% due to the training's special characteristics) and the PMFEIT (76.73\%). The study program is financed by the state in $60.30 \%$ of the cases and only $33.45 \%$ of the graduates have to pay for their tuition (the rest in both types). Similar tendencies can be observed from the data in the case of state financed places with the exception of the FHS, which has an elevated ratio $(90.26 \%)$ of state-financed former students.

To determine the potential target groups of the Alumni Program, we have to identify what the main characteristics of the available UP graduates are. The following variables are important: income, territorial distribution, job position, awareness of the Alumni Program and the work related skills and competences concerning the income and the job position.

In Table 2 we can observe the graduates' net income in thousands of HUF. The data was corrected by the general net income increase in the different sectors. It is a natural tendency that the average is lower with less time passed between the graduation and the inquiry. There is an exception, the last year, which possibly indicates the beginning of the way out from the financial crisis of the past couple of years. The MS is characterized by the greatest variance, which is for sure due to the low number of respondents and the enormous differences in this profession. In 2012 the net minimum wage in Hungary was $62,880 \mathrm{HUF}$, and the average net salary for the white-collar workers 183,199 HUF, so we can say that the students, who graduated five years earlier, earn almost the Hungarian average, but the graduates of 2011 are in a good position too. Of course there is a huge difference among the regions, in the capital the average net income of the newly graduated was 166,054 HUF and those who decided to work abroad earned 480,040 HUF.

Table 2. The graduates' net income in thousands of HUF, 2007-2011

\begin{tabular}{|l|c|c|c|c|c|c|c|c|c|c|}
\hline \multirow{2}{*}{$\begin{array}{c}\text { Faculties/ } \\
\text { Net } \\
\text { income }\end{array}$} & \multicolumn{2}{|c|}{$\mathbf{2 0 0 7}$} & \multicolumn{2}{c|}{$\mathbf{2 0 0 8}$} & \multicolumn{2}{c|}{$\mathbf{2 0 0 9}$} & \multicolumn{2}{c|}{$\mathbf{2 0 1 0}$} & \multicolumn{2}{|c|}{$\mathbf{2 0 1 1}$} \\
\cline { 2 - 12 } & Mean & $\begin{array}{c}\text { Standard } \\
\text { Deviation }\end{array}$ & Mean & $\begin{array}{c}\text { Standard } \\
\text { Deviation }\end{array}$ & Mean & $\begin{array}{c}\text { Standard } \\
\text { Deviation }\end{array}$ & Mean & $\begin{array}{c}\text { Standard } \\
\text { Deviation }\end{array}$ & Mean & $\begin{array}{c}\text { Standard } \\
\text { Deviation }\end{array}$ \\
\hline FL & 173.16 & 107.93 & 173.52 & 113.38 & 157.78 & 70.40 & 134.95 & 81.06 & 137.58 & 65.75 \\
\hline MS & 180.27 & 36.16 & 255.70 & 242.11 & 275.32 & 304.76 & 148.89 & 121.36 & 364.39 & 331.79 \\
\hline FH & 152.09 & 100.80 & 148.25 & 81.60 & 166.99 & 139.99 & 116.40 & 83.41 & 125.72 & 74.75 \\
\hline FHS & 178.34 & 160.35 & 144.10 & 96.46 & 128.28 & 75.65 & 107.99 & 37.24 & 109.37 & 52.96 \\
\hline FAEHRD & 180.77 & 98.77 & 176.66 & 91.23 & 161.85 & 82.33 & 149.25 & 124.51 & 159.00 & 74.93 \\
\hline IGyFE & 126.82 & 51.95 & 122.75 & 55.85 & 123.39 & 69.93 & 103.73 & 45.32 & 100.87 & 76.32 \\
\hline FBE & 273.18 & 201.02 & 192.61 & 79.02 & 195.69 & 124.03 & 131.88 & 64.10 & 169.55 & 115.21 \\
\hline FMVA & 148.32 & 59.59 & 176.83 & 103.65 & 111.41 & 38.69 & 95.22 & 23.68 & 102.71 & 29.44 \\
\hline PMFEIT & 181.81 & 94.61 & 168.60 & 100.24 & 175.70 & 162.50 & 129.57 & 53.68 & 155.53 & 150.85 \\
\hline FS & 129.47 & 39.06 & 135.89 & 55.19 & 152.67 & 113.71 & 122.04 & 125.51 & 135.17 & 65.28 \\
\hline Total & $\mathbf{1 7 6 . 5 1}$ & $\mathbf{1 2 2 . 2 4}$ & $\mathbf{1 6 5 . 0 4}$ & $\mathbf{1 0 4 . 3 6}$ & $\mathbf{1 6 2 . 7 3}$ & $\mathbf{1 2 5 . 2 4}$ & $\mathbf{1 2 4 . 9 5}$ & $\mathbf{8 4 . 5 5}$ & $\mathbf{1 4 7 . 4 4}$ & $\mathbf{1 2 2 . 3 3}$ \\
\hline
\end{tabular}

Source: Authors' research 
To analyse the regional distribution of the graduates, we should examine the two maps of Hungary in Figure 3. (The 1.37\% of the students living abroad at the age of 14 and the $5.42 \%$ of the former students working abroad are not shown on the maps.) Based on the upper map, we can observe a very intensive regional character of the University of Pécs, almost half (49.27\%) of the former students lived in the South Transdanubian region (Baranya, Somogy and Tolna counties) and only $7.51 \%$ in the capital at the age of 14 . After their labour-market entry we find that $22.18 \%$, almost $15 \%$ more work in Budapest. The sources of this immigration to the capital are Somogy and Tolna county and the West Transdanubian region too, only Baranya did not lose from its original position. This trend clearly shows the talent migration and the concentration of the skilled workforce in the capital, which greatly affects regional competitiveness. One of the major reasons for the migration to Budapest is that it is easier to find a job there - and starting salaries are higher as well. But beside this negative tendency, it is important to realize, that almost $42.91 \%$ work within a $100 \mathrm{~km}$ radius from the UP (considering only the city of Pécs). So in the period 2007-2011, based on the GFS search 5,587 working graduates can be reached easily and some kind of service can be offered to them.
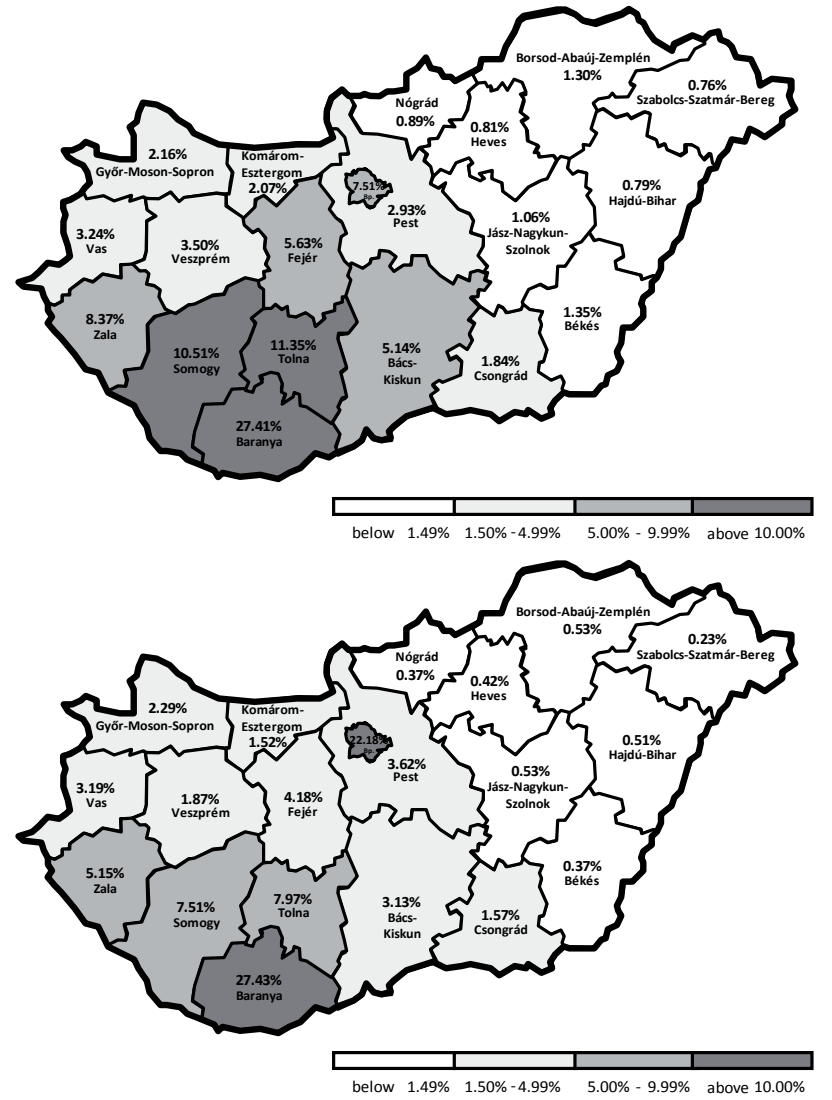

Figure 3. The graduates' county at the age of 14 (above; $\mathrm{n}=4,097$ ) and the workplace's county (below; $\mathrm{n}=3,188$ ).

Source: Authors' research.

Table 3 illustrates the regional distribution of the job position in the three counties in a $100 \mathrm{~km}$ radius of the UP to determine the possible target groups participating in the Alumni Program. It has almost the same proportion in the counties, but there is a statistically significant difference $(\mathrm{p}=0.000)$, which might show us the different possibilities due to the industrial activities in the counties. However, the major part of the graduates work as employees, of whom 
$62.11 \%$ hold a position which requires a higher educational degree and $20.70 \%$ in a profession which does not. Only $17.19 \%$ work as managers (of course with time this proportion increases significantly), so the possible services have to be focused around the needs of a more regular, determined circle of professions.

Table 3. The graduates' distribution in the South-Transdanubian region by the job position $(\mathrm{n}=1,251)$.

\begin{tabular}{|l|c|c|c|c|c|}
\hline $\begin{array}{c}\text { Job county/ } \\
\text { Job position }\end{array}$ & $\begin{array}{c}\text { Top } \\
\text { management }\end{array}$ & $\begin{array}{c}\text { Middle } \\
\text { management }\end{array}$ & Other manager & $\begin{array}{c}\text { Employed } \\
\text { graduate req. }\end{array}$ & $\begin{array}{c}\text { Employed non } \\
\text { graduate req. }\end{array}$ \\
\hline Baranya & $3.26 \%$ & $8.65 \%$ & $3.88 \%$ & $62.78 \%$ & $21.43 \%$ \\
\hline Somogy & $8.72 \%$ & $8.26 \%$ & $3.21 \%$ & $67.43 \%$ & $12.39 \%$ \\
\hline Tolna & $2.98 \%$ & $9.79 \%$ & $6.38 \%$ & $54.89 \%$ & $25.96 \%$ \\
\hline Total UP & $\mathbf{4 . 1 6 \%}$ & $\mathbf{8 . 7 9 \%}$ & $\mathbf{4 . 2 4 \%}$ & $\mathbf{6 2 . 1 1 \%}$ & $\mathbf{2 0 . 7 0 \%}$ \\
\hline
\end{tabular}

Source: Authors' research.

Table 4 confirms the pertinence of the different job occupation levels, because we can see an unequivocal sequence in the salary from the top management to those employed with a job that does not require a degree and furthermore it is quite obvious (compared with Table 2) that the single datasets within the groups are more consistent, because the standard deviations are much lower.

Table 4. The graduates' net income (in thousands of HUF) by the job position in the South-Transdanubian region $(n=1,251)$.

\begin{tabular}{|l|c|c|c|c|c|c|c|c|c|c|}
\hline \multirow{2}{*}{$\begin{array}{c}\text { Job county/ } \\
\text { Job position } \\
\text { Income }\end{array}$} & \multicolumn{2}{|c|}{ Top management } & \multicolumn{2}{|c|}{ Middle management } & \multicolumn{2}{c|}{ Other manager } & \multicolumn{2}{|c|}{$\begin{array}{c}\text { Employed graduate } \\
\text { req. }\end{array}$} & \multicolumn{2}{c|}{$\begin{array}{c}\text { Employed non } \\
\text { graduate req. }\end{array}$} \\
\cline { 2 - 12 } & Mean & $\begin{array}{c}\text { Standard } \\
\text { Deviation }\end{array}$ & Mean & $\begin{array}{c}\text { Standard } \\
\text { Deviation }\end{array}$ & Mean & $\begin{array}{c}\text { Standard } \\
\text { Deviation }\end{array}$ & Mean & $\begin{array}{c}\text { Standard } \\
\text { Deviation }\end{array}$ & Mean & $\begin{array}{c}\text { Standard } \\
\text { Deviation }\end{array}$ \\
\hline Baranya & 209.7 & 58.7 & 185.1 & 99.6 & 140.1 & 42.4 & 122.5 & 58.0 & 97.8 & 35.0 \\
\hline Somogy & 177.9 & 62.3 & 164.3 & 55.2 & 122.9 & 15.3 & 124.6 & 46.9 & 114.8 & 127.4 \\
\hline Tolna & 203.7 & 74.7 & 175.2 & 90.9 & 184.7 & 84.4 & 134.6 & 80.1 & 115.0 & 145.2 \\
\hline Total UP & $\mathbf{1 9 6 . 8}$ & $\mathbf{6 2 . 9}$ & $\mathbf{1 7 9 . 5}$ & $\mathbf{9 1 . 3}$ & $\mathbf{1 5 1 . 2}$ & $\mathbf{5 9 . 5}$ & $\mathbf{1 2 4 . 9}$ & $\mathbf{6 0 . 4}$ & $\mathbf{1 0 3 . 6}$ & $\mathbf{8 5 . 9}$ \\
\hline
\end{tabular}

Source: Authors' research.

When analysing the Table 5 we have to consider the data from above, more precisely the proportions of the single job positions. The managers are relatively few and so the results are to be interpreted with a certain reservation. The column 'aware' shows the proportion of the groups who have ever heard of the existence of the UP Alumni Program, the 'membership' indicates the ratio of those who are members (if they have heard about the Program), and the final column indicates those who already used a service (if they are members of the Program). This means that a high level of service used (even if apparently this is not the case) can represent a very small number of respondents. We can see that an elevated level of Alumni Program awareness is achieved in every group in the past few years. From the year of 2007 (62\%) the awareness increased to above 80\% in 2011. Approximately $25 \%$ of those who work in a job where a degree is required are 
members of the UP Alumni Program, except the non-graduate required workers, where the membership only reaches $13,75 /$, of course this number is also increasing with time. Which is a rather disappointing result (or at least it seems to be) is the service used by the graduates, which is only $2-5 \%$. To know the right value of this ratio we have to present the UP Alumni Program history and current results.

Table 5. The graduates' Alumni related information (awareness, membership, service used) by the job position in the South-Transdanubian region $(n=1,251)$.

\begin{tabular}{|c|c|c|c|c|c|c|c|c|c|c|c|c|c|c|c|}
\hline \multirow{2}{*}{$\begin{array}{c}\text { Job county/ } \\
\text { Alumni } \\
\end{array}$} & \multicolumn{3}{|c|}{ Top management } & \multicolumn{3}{|c|}{ Middle management } & \multicolumn{3}{|c|}{ Other manager } & \multicolumn{3}{|c|}{ Employed graduate req. } & \multicolumn{3}{|c|}{ Employed non graduate req } \\
\hline & & Member & & & Member & Service & & & & & & & & & \\
\hline & & & & & & & & & & & & & & & \\
\hline & & & & & & & & & & & & & & & \\
\hline & & $37.39 \%$ & & & & & & & & & & & & & \\
\hline otal or & $68.64 \%$ & $23.29 \%$ & $5.57 \%$ & $73.55 \%$ & $26.07 \%$ & $2.60 \%$ & $72.13 \%$ & $25.24 \%$ & $0.00 \%$ & $78.64 \%$ & $25.73 \%$ & $3.52 \%$ & $67.73 \%$ & $13.75 \%$ & 007 \\
\hline
\end{tabular}

Source: Authors' research.

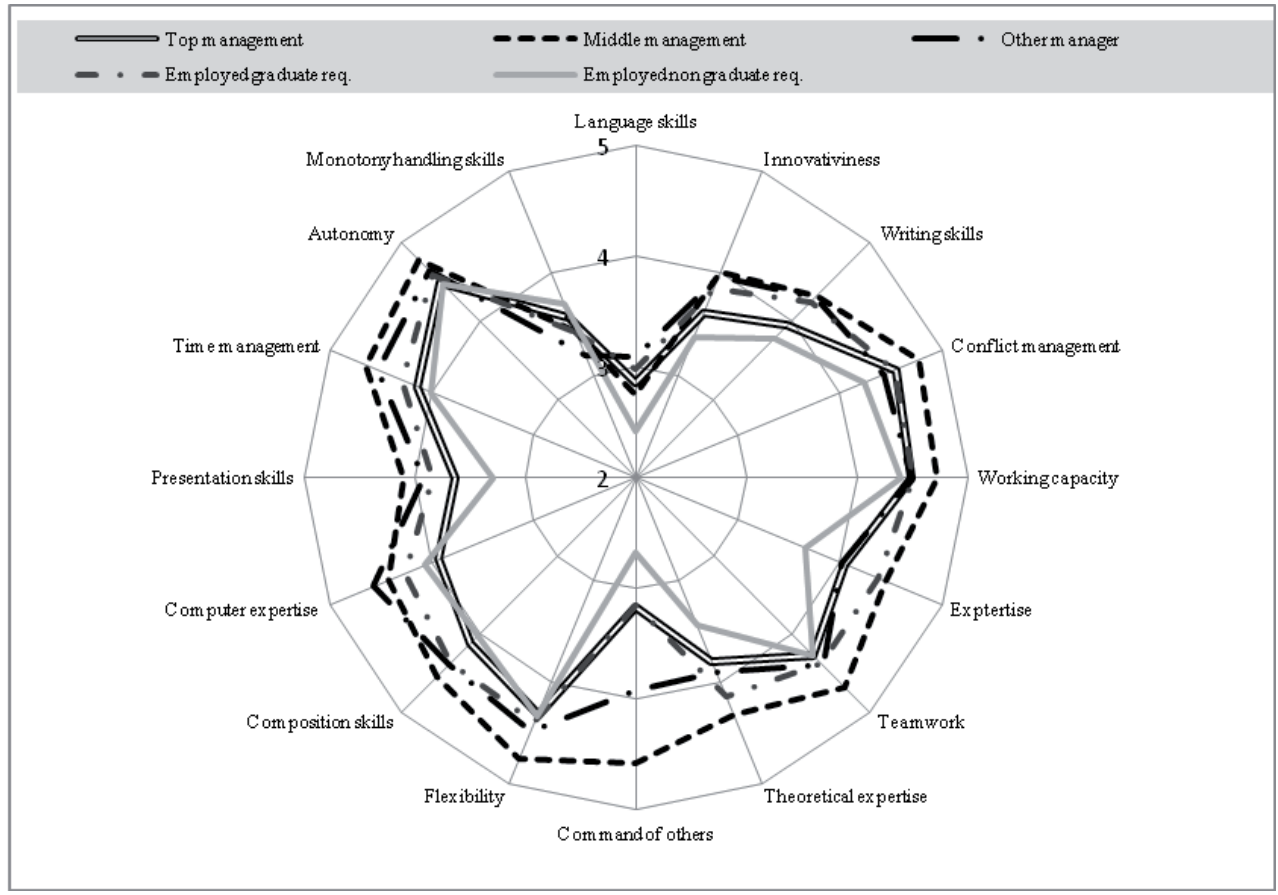

Figure 4. Working-related skills by the job position $(n=1,215)$.

Source: Authors' research.

But before this, as a last analysis of the GFS survey in this study we can observe in Figure 4 the job-related skills for the different positions. The question block consists of 16 questions on a 5 grade scale (where 5 means the high level of skills required for the job) and it is based on the Marketing Office's (mainly on the marketing leader's, Gabriella Kuráth's) previous experience in different researches carried 
out at the University of Pécs. The identification of the different groups' necessary skill level facilitates the creation of the appropriate packages to be offered to the members of the Alumni Program.

As we can see, the results show us a very interesting picture, because it is quite obvious that the necessity of skills should be verified by the existence of a descending order from the top management to the employee status which does not require a degree. There is an exception, however, namely the monotony skill, which is present vice versa naturally. Nonetheless, the top managers scored the highest in none of the above mentioned skills, but they gave an average in each case. On the lower levels the expectations are proved, and the scores concerning the necessary skills are descending from the middle management to the employees who work in a job where a degree is not required. This can suggest, that the top managers need other types of competences and skills, probably a wider, long-term strategic vision and an extensive business social network, because their value creation is not only based on their lives at the workplace but their leisure related activities. The middle management and other managers are those who have to use a wide range of skills every day to be able to remain operational in business, to handle the employees and to ensure the effectiveness of every single process. In almost every skill the middle management gave the highest scores, so they have to be up to date, to seek the new technologies, methods. This means that they have to participate in different trainings regularly. As discussed above, they have a relatively high level of income, so they are capable and willing to pay more for a valuable training (this is an important factor even if they are low in number). The other managers are close to the middle management, so their needs can be linked to them. The employees form another target group. They have to develop their skills to be able to earn a promotion; meanwhile they earn less and therefore have less capital to invest into their training. Since studying is a natural process of development, they do not need that kind of professional package at this stage (neither in terms of quality nor focus) as the managers, therefore training can be offered to them at a lower price.

\section{The Alumni PRogram OF THE UNIVERSITY OF PÉCS}

The University of Pécs reached its present stage in 2000 by the fusion of three institutions and therefore there is a demand for a unified, common platform to reach the former students. The three independent institutions and the faculties in them operated different alumni programs with little or no connection with each other. On 22 January 2001 the Senate of the UP ratified the regulation of the Pécs Alumni Circle (which later became part of the Alumni Office projects) under the authority of the central Marketing Office supervised by the vice-rector for finances, strategic planning and communication. Based on this Circle the UP created the Alumni Program of UP in the last decade, the goal of which is to enhance the efficiency of every single alumni program by providing them with different types of services. This means that the faculties have their autonomy; furthermore their efforts are facilitated based on the central office's activities. 
The Alumni Program (AP) of UP synthesizes the faculty programs and (in case it is needed) helps to contact the potential sponsors and participants. To strengthen the possibilities to reach students and graduates, a database was created of those who asked for membership of the AP (the membership is free; however, there is a possibility to support the UP with a small fee). Today $(15 / 12 / 2012)$ the Alumni Program has 10,917 members (alumni.pte.hu), who all received a plastic card which per sé can be used for obtaining several services at a discount price or free (for example the access to the Central Library of Pécs), and the list of services is broadening steadily. Thanks to this database the unpleasant reaction to multiple accesses due to the huge and cross-related institutional datasets can be avoided. A website was created to inform the former students about the possibilities, programs and events of the UP and the faculties (the GFS results can be accessed on this site as well). It is not a static website in the sense that after the registration it would be superfluous to visit, on the contrary in the ulterior cases it offers access to important tasks, such as the registration for different programs (organized by the UP, or the faculty of the graduate), small surveys for a price etc.

The former students receive a periodic newsletter (based on the GFS results this is undoubtedly the most adequate way to reach them), which contains the most important events, and there is an annual periodical, the PRIZMA Magazine, to be given to newly graduated students at the graduation ceremony. Beyond these events, the AP staff consider it essential to be present at every major event to contact former and current students. It is a new way of letting the present students know that they can become members of the AP, which can intensify the connection to them during their studies and hopefully this allows the creation of more personalized services after their graduation.

The University of Pécs as a higher educational institution has the goal of ensuring that it meets the demands of the labour-market, and to provide students with the appropriate knowledge and skills for a successful career start. The Graduate Follow-Up System provides the UP with the necessary information to help broaden the services offered to graduates through the Alumni Academy. The GFS results formed the basis of the project in the sense of the identification of the necessary skills to develop, and the target groups to be reached. After a thorough review of the available programs on the market and a further, more concrete (enumerating some alternatives) survey of the former students, a variety of services were determined. These packages are one-day long (on Saturdays) competence developing programs in the required areas. After some debate at the start of the program, the program generally focuses on those employees who want to achieve a higher level of skills to pass onto their workplace. On one hand it was important to limit the potential group of participants to ensure the success of the initiative; on the other hand, the top managers are less in number and only after the deep understanding of the 'simple' employees' needs and the conclusions drawn from the program it can be extended to the higher job positions. The other priority factor was the amount of money to charge. These programs in Hungary cost from $30,000-60,000 \mathrm{HUF}$ and so the UP determined the price at a level of 28,000 HUF + VAT per capita for everybody and with a discount of more than $60 \%$ (only 8,000 
HUF + VAT for the members of the Alumni Program, so basically the members pay $10 \%$ of their net income for a training). The trial period was in the academic year of 2011/12 at the start of 5 training sessions, mostly around the main thematic of the job-related development (one of them was a non-job-related training: wine-culture). The acceptance of this initiative was a success which stimulates its continuation and the further personalization of the packages in 2012/13 (Kuráth, Németh, 2011).

\section{CONCLUSIONS}

The Graduate Follow-Up System survey focuses on several different aspects emphasizing the major important variables, which provides the government with useful input for the Higher Education Information System and so the higher education strategic planning. From the sociological questions to the multiand interdisciplinary blocks regarding economic aspects and everyday life, the GFS is a database on a wide variety of information. Hopefully the universities will handle this obligatory task as a unique opportunity to enhance and improve the services for present and former students. The alumni systems can provide benefits for both the institutions and the graduates by creating and maintaining a reciprocal contact with benefits. The University of Pécs has already developed the Alumni System with more than 10,000 members, which can be strengthened and amplified by the repeated work of GFS and vice versa, the Alumni database can assure a greater number of more active respondents for the GFS survey (Kuráth, Németh, 2011).

The results are important from the point of view of the Hungarian Higher Education System, because the institution represents $7.74 \%$ of the total number of higher education students, therefore the lessons learned can be used in the creation of a sustainable strategy and service improvement.

\section{REFERENCES}

alumni.pte.hu (2012). Retrieved December15, 2012 from: http:/ /alumni.pte.hu,

Felvi.hu (2012). Retrieved December 15, 2012 from: http://www.felvi.hu/felveteli/ponthatarok_rangsorok/elmult_evek/!Elmult Evek/elmult_evek.php?stat $=4$

KSH (2012). Retrieved December 15, 2012 from: http://www.ksh.hu/docs/hun/xstadat/xstadat_hosszu/h_wdsi001b.html

Kuráth, G., Kovács, Á., Kiss, T., Héráné, A. T., Sipos, N. (2011a). Diplomás Pályakövetö Rendszer - 2011-es pályakövetési vizsgálat a Pécsi Tudományegyetemen [Graduate Follow-up System - 2011 follow-up survey at the University of Pécs]. Pécs: University of Pécs.

Kuráth, G., Kovács, Á., Kiss, T., Héráné, A. T., Sipos, N. (2012). Diplomás Pályakövetö Rendszer - 2012-es pályakövetési vizsgálat a Pécsi Tudományegyetemen [Graduate Follow-up System - 2012 follow-up survey at the University of Pécs]. Pécs: University of Pécs.

Kuráth, G., Kovács, Á., Kiss, T., Szűcs, K., Tiszberger, M., Héráné, A. T., Sipos, N. (2011b), Diplomás Pályakövetö Rendszer - 2010-es pályakövetési vizsgálat a Pécsi Tudományegyetemen [Graduate Follow-up System - 2010 follow-up survey at the University of Pécs]. Pécs: University of Pécs.

Kuráth, G., Németh, P. (2011). A DPR eredményeinek hasznositása az alumni rendszerek épitésekor a Pécsi Tudományegyetem példáján [The use of the GFS results in the alumni system development at the University of Pécs]. In: Cs., Obádovics (ed.), Diplomán innen és diplomán túl: DPR Tanulmányok [Before and after degree: GFS Studies] (pp. 183-190). Gödöllő: Szent István Egyetem. 
Magyar Közlöny (2011a). 2011. évi CCIV. törvény a nemzeti felsőoktatásról [Act CCIV of 2011 On National Higher Education]. Magyar Közlöny, 165, 41181-41247. Retrieved from: http:/ /jogszabalykereso. mhk. hu/MK11165.pdf

Magyar Közlöny (2011b), Magyarország Alaptörvénye [Fundamental Law of Hungary]. Magyar Közlöny. 43, 10656-10682. Retrieved from: http://www.kormany.hu/download/0/d9/30000/Alapt\%C3\%B6rv\% C3\%A9ny.pdf

Magyar Közlöny (2012). 1007/2012. (I. 20.) Kormány határozat a 2012-ben a felsőoktatásban felvehető, államilag támogatott hallgatói létszámkeretról [Government resolution 1007/2012 (I. 20.) on the number of state funded places in higher education in the academic year 2012/13]. Magyar Közlöny, 6, Retrieved from: http://www.kozlonyok.hu/nkonline/ MKPDF/hiteles/MK12006.pdf

Oktatási Hivatal (n.d.). Retrieved December 15, 2012 from: http://www.oktatas.hu/felsooktatas/ felsooktatasi_statisztika

Pte.hu (n.d.). Retrieved December 12, 2012 from: http:/ / www.pte.hu/index.php?p=contents\&cid=2536

Sajtos, L., Mitev, A. (2007). SPSS kutatási és adatelemzési kézikönyv [The handbook of SPSS research and data analysis]. Budapest: Alinea Kiadó.

Szolár, É. (2009). Az európai felsőoktatás átalakulása és a Bologna-folyamat céljai [The restructure of the European higher education and the goals of the Bologna Process]. Iskolakultúra, 19(9), 95-119. 